\title{
Value Proposition Transformation and Humanistic Spirit Construction of the Ideological and Political Education in Colleges
}

\author{
Yongkun $\mathrm{Yu}$ \\ Jilin Agricultural University, Changchun 130118, China
}

\begin{abstract}
Under today's background of social and economic structure, culture forms, values and ways of life developing, China still follows the traditional education mode, ways and methods. In consequence, the ideological and political education becomes more and more difficult to adapt to the changes of the times and social development, and it is harder and harder to meet the needs of the reality of the situation. In the face of the new situation and new tasks, ideological and political education in Colleges only through enhancing its attractiveness, appeal and persuasive to improve the pertinence, activity and effectiveness. Only by continuous reform and innovation can keep pace with the times under the background of new era and explore the new developing road. This paper, based on this purpose, taking Kuhn's paradigm theory as the breakthrough point, analyzes the paradigm theory, does research on the feasibility and necessity of the study of the ideological and political education. The connotation of social ideological and political education paradigm and humanistic ideological and political education paradigm and also the relationship between are discussed in this paper. In the end of this paper, the paths for the construction of the humanistic paradigm is put forward. It aims at initiating the development of ideological and political education, and provide helpful research methods and ideas.
\end{abstract}

Keywords: ideological and political education; value proposition; humanistic spirit.

\section{Introduction}

As the development of reform and opening up, China has witnessed the earth shaking changes of socialist China and life of Chinese people. Facing the new background of the times and the new practical environment, continuous reforms and innovations are necessary in order to keep pace with the times under the background of new era. In recent years, the paradigm of ideological and political education becomes a new hot topic for experts' and scholars' research. Taking Kuhn's paradigm theory as the breakthrough point, this paper, analyzes Kuhn's theory of paradigm. First of all, the feasibility and necessity of Kuhn's paradigm theory applied to the ideological and political education is analyzed, which sets the theoretical premise for the paper. Moreover, this paper, from the perspective of setting up the correct ideological and political education idea, innovating ideological and political education content, optimizing the ideological and political education work methods, and improving the ideological and political education management and evaluation mechanism, puts forward their own views and suggestions, and tries to explore a set of complete method system, so as to better promote ideological and political education and humanistic spirit construction.

\section{Interpretation of Ideological and Political Education Paradigm in Colleges and Universities}

\subsection{Paradigm and Paradigm Transformation}

In the preface of Kuhn's first work The Copernican Revolution: Planetary Astronomy in the Development of Western Thought, he used the word "Paradigm" for the first time. In the postscript of the book the structure of scientific revolution, Kuhn emphasizes the two meanings of "paradigm". On the one hand, it represents the common belief, value and technology of a specific community members; on the other hand, it refers to predicate an element of the overall, namely answer for the puzzle. Take them as a model and example, it is possible to replace the clear rules as a basis for the answer for the puzzle in general science. In a word, Kuhn's "paradigm" refers to relatively stable 
common beliefs, ways of thinking and value standard of all the members in a specific field, which is a research model integrating a set of theoretical and practical significance.

Kuhn believes that, in a certain period of time, the scientists' research complies with a certain point of view, and in practice takes it as a guide to transform the objective world. They are engaged in scientific research and practical activities in accordance with the existing research paradigm. This phenomenon is called "general science". In the period of "scientific revolution", scientists broke the shackles of the old paradigm, and took a new perspective and method to think and solve problems, and gradually formed a new framework of understanding, until the emergence and establishment of a new paradigm, which is said the establishment of the "New General Science". The establishment of "New General Science" indicates the generation of the new paradigm, and the process is called "paradigm shift". Its development process is shown in figure 1.

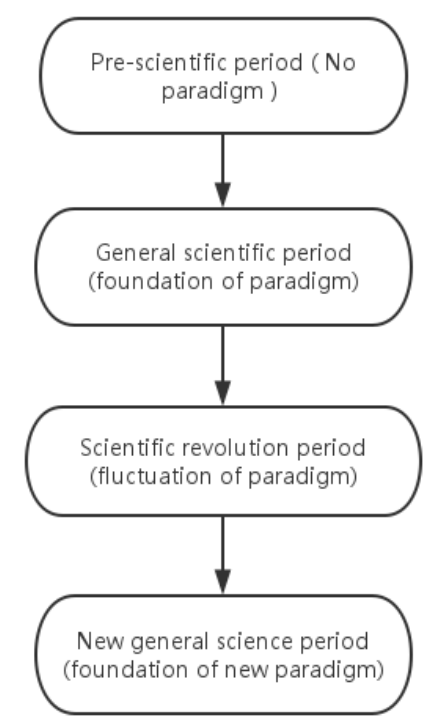

Figure 1 Sketch Map of Kuhn Paradigm Shift

\subsection{Paradigm of Ideological and Political Education in Colleges and Universities}

For a long time, the ideological and political education guided by the social paradigm, always occupies the leading position in the Colleges. It can be said that this kind of paradigm over-emphasizes the social value of ideological and political education, and it is a kind of education which is guided by the social need and the tool value. The value relationship is mainly displayed in two aspects, as shown in figure 2.

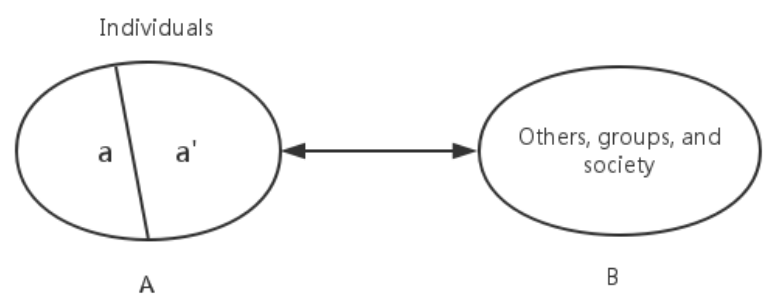

Figure 2 Value Relationship Pattern

One is the relationship between $\mathrm{A} \rightarrow \mathrm{B}$, namely the individual $\mathrm{A}$ is regarded as the value object of the social subject B. At this time, A's value to B can be referred to as "social value", which is the satisfaction of individuals to others, groups and social needs. The satisfaction of this kind of need, in essence, is the contribution and creation of the individual to others, group and society, and it is a kind of social value "for his value" or "social value". The social value reflected by individuals will in turn appear on him, namely B $\rightarrow$ A. Another is the relationship of the individual's own A $(a \rightarrow a$ '). As in 
Marx's view, in any historical condition, people are going to do something for their own needs a'. At this time the individual A takes the behavior a as the object of the value. In other words, the individual A constitute the relationship between the subject and object in their own needs a' and behavior a. In this case, the behavior of the individual a shows the satisfaction of their own needs, then his value is "value for me" or "self value".

Under the current social environment, the number of problems college students encounter in learning and living many problems is increasing, such as employment problem, interpersonal relationship problem, and psychological problem. According to the annual "China Statistical Yearbook" in 2005 - 2014, the number of college graduates in China has remained high in recent years, as shown in figure 3. Data in the figure reflects the problems encountered by college students in their daily life. The ideological and political education is rooted in the life of college students, and life is the source of ideological and political education.

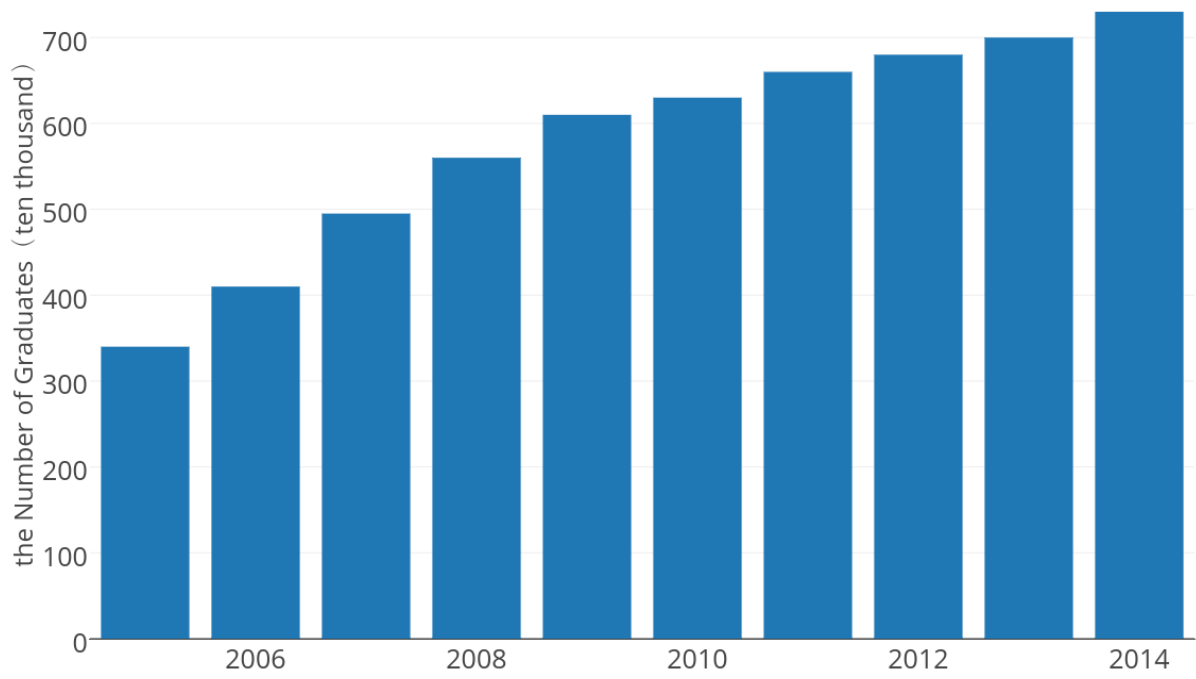

Figure 3 the Number of Graduates in Colleges and Universities in China from 2005-2014

\section{Paradigm Transformation of Ideological and Political Education in Colleges and Universities}

\subsection{Establish the Correct Idea of Ideological and Political Education}

Facing the new situation and new tasks, the ideological and political education in Colleges and universities expecting to effectively do the work of conducting a man well must adhere to take the students as the core, respect students, understand students, care for students and inspire students, and continuously push forward the development of educational work. China's traditional man-oriented thought regards man as the soul of the universe of heaven and earth, expresses an awe of life, care and respect to the value and significance of man, and reflects the connotation of the humanistic spirit. Set up the consciousness of respecting the students' subject. In the rapid development of China's society, and constantly changing background, people's self-consciousness, and the consciousness of the main body are suddenly strengthened that they begin to pay more attention to themselves. College students grown in this social environment are naturally affected by the impact of this social atmosphere so that their self-awareness, the main body of consciousness are greatly enhanced. Therefore, in order to set up the ideological and political education concept of taking students as the core, educators should firstly establish awareness of respecting for students, give students full freedom to play, meet the students' participation and performance demand, and play the subjective initiative of the students.

\subsection{Optimize Ideological and Political Education Work Method}

\subsubsection{Pay Attention to Close Combination of Theory and Practice}

Under the shackles of the social-oriented paradigm, the ideological and political education in Colleges and universities will often emphasize theory while ignore practice. The education theory always represents the abstraction and dogmatization and other problems, which to a certain extent 
results in inefficiency of the current ideological and political education in Colleges and universities. Therefore, the ideological and political education in Colleges and universities should be oriented to practice, pay attention to the combination of theory and practice, enrich the practical activities of ideological and political education, and build a practical people-oriented education paradigm. Enrich the practice of ideological and political education in Colleges and universities. On the basis of carrying out practical activities, the school party organization in Colleges and universities should stimulate students' consciousness of teaming, making independent project, fully mobilize the power of student organizations, villager's autonomous organizations to expand the coverage and influence of the practice. Consider the needs of different students in different levels, Colleges and universities should use their own advantages to choose a representative institution as a practice base, replace previous single mode of only observing and visiting, establish a convenient and stable cooperative relationship, combine the ideological education of college students with social practice, and strive to build a unique brand of social practice of college students.

\subsubsection{Focus on Humanistic Care and Psychological Counseling}

Mental health problems that embodied by College students in learning, making friends, employment and other aspects not only make great influence on the physical and mental health, also result in the increase of the university student illegal crime events in recent years. According to the survey of Chinese Criminology Research, "in 1965, the crime of college students accounted for $1 \%$ of the juvenile delinquency; in recent years, the crime of college students accounted for $17 \%$ of the juvenile delinquency, and accounting for the total number of $1.26 \%$. How to prevent and solve the mental health problems and criminal problems of college students has become the era task of ideological and political education in Colleges and universities, which is the intrinsic requirement of constructing people-oriented education paradigm. Pay attention to the mental health education of college students, improve the understanding of mental health of College students. Mental health problems have seriously affected the growth of college students, and college students generally lack correct understanding and awareness of mental health problems. Survey shows that nearly $40 \%$ of college students choose do not to tell anyone when they encounter trouble or feel depressed. These psychological problems could not be effectively resolved, then grow a variety of negative emotional contagions. Therefore, colleges and universities should pay great attention to the students' mental health problems, increase mental health publicity and education efforts, regularly organize lectures on mental health, and actively carry out positive cultural activities, so as to improve college students' knowledge and understanding of mental health problems.

\subsection{Improve the Management and Evaluation Mechanism of Ideological and Political Education}

The full play of the function and role of ideological and political education in Colleges and universities cannot be separated from the guarantee of a scientific, rational, and efficient management and evaluation mechanism. It is necessary to reform and improve the management and evaluation system of ideological and political education in Colleges and universities for the construction of people-oriented education paradigm.

\subsubsection{Implement Humanized Management Mechanism}

Educational management system plays an important role in the ideological and political education of the students. It can be said that the smooth progress of ideological and political education depends on a scientific education management mechanism. Colleges and universities ideological and political education people-oriented paradigm requires us to implement scientific and humanized management mode, establish scientific and effective management mechanism that each performs its own function but also cooperate with each other.

Give full play to the role of the party, government, industry, the group and the teacher to form a joint force in education. A clear limitation of most of the current college ideological and political education is too dependent on the political model, overemphasize the supremacy of administrative power, and management is single. In the school system, all the staff of the systems are responsible for the education and training of people. Specialized course teachers should deeply excavate the value of 
ideological and political education, and consciously integrate daily ideological and political education into all aspects of College students' professional learning, and permeate all aspects of teaching and scientific research.

Gradually realize the students' self-management. Colleges and universities staffs, especially the workers in the ideological and political education should devote themselves to improvement of the norms and institutions, establish an educational management mechanism with humanized characteristics and feasibility. This management mechanism is a progressive process system of "management itself management process management purpose". Its ultimate goal is to let students improve their self-control and self-development ability under the guidance of a certain ideology and values, so as to improve the effect of ideological and political education, and finally achieve the goal of students' self-education, self-service and self-growth.

\subsubsection{Establish Scientific and Reasonable Evaluation Mechanism}

Evaluation of ideological and political education in Colleges and universities is the senior management, school or educator according to the evaluation content, the steps, processes and the corresponding methods, evaluate and measure the elements of ideological and political education of college students and the education effect. Ideological and political education evaluation is an important supervision and guiding mechanism of ideological and political education in Colleges and universities, which is an indispensable part of a complete educational process. People-oriented education paradigm requires to reform and improve the evaluation mechanism of ideological and political education and establish a scientific and rational evaluation system, as it is shown in figure 4.

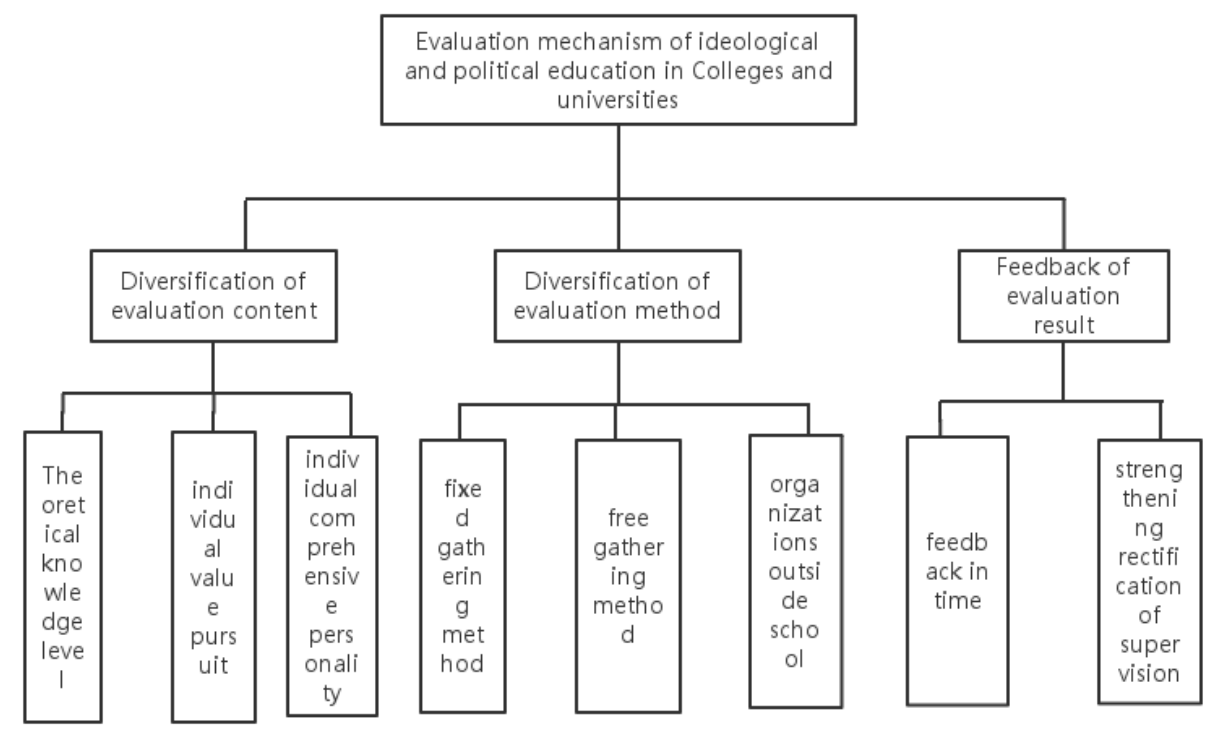

Figure 4 Evaluation Mechanism of Ideological and Political Education

\section{Conclusion}

Ideological and political education in Colleges and universities is the main position of college education. With the development of the environment of the times, the contemporary university students also show a lot of new changes and new features. The social-oriented paradigm of ideological and political education becomes unable to adapt to these changes. Therefore, conform to the requirements of the times, adhere to and explore the ideological and political education paradigm, improve the ideological and political education of the times, is the inevitable choice of ideological and political education in Colleges and universities in the new era. In Kuhn's paradigm theory, through analysis on the paradigm transformation of the University ideological and political education, explains the era proposition of the ideological and political education by society-oriented paradigm to 
people-oriented paradigm. By this transformation, College ideological and political education can better develop, and the construction of humanistic spirit will be promoted.

\section{References}

[1] Zhichao. The Method and Effects of Micro-blog Carrier in Ideological and Political Education [J]. Theory Research, 2015, 11: 113.

[2] Fang Yan. Agenda Setting Theory: the Path of College Ideological and Political Education in the Context of New Media [J]. 2016.

[3] Wang Ye. Big Data Era Influence on College Students' Ideological and Political Education and Innovation Strategy[C]//2016 Eighth International Conference on Measuring Technology and Mechatronics Automation (ICMTMA). IEEE, 2016: 126-128.

[4] Li Zi-ye. Research on the Measures of Strengthening the Effectiveness of Ideological and Political Education in Colleges [J]. 2015.

[5] Bin T, Junjun X U E. Carry Forward the Spirit of the Heroes of Anti-Japanese War, and Promote the Ideological and Political Education of College Students [J]. Cross-Cultural Communication, 2015, 11(11): 1-5.

[6] Shan Tang. Change of Ideological and Political Education Strategy under New Media Environment [J]. 2015.

[7] Gong, F., Diao, Y., Pan, T., Liu, M., \& Sun, H. (2015). Evolution of human medical model and development course of medical humanistic spirit.Biomedical Research, 26(3), 407-414.

[8] Pei, Shixin, Fenping Cui, and Tingting Sun. The unity of scientific literacy education and humanistic spirit education in higher education. Creative Education 3.07 (2013): 121. 